\title{
Photosynthesis, growth, and yield of Paeonia ostii in tree-based agroforestry systems
}

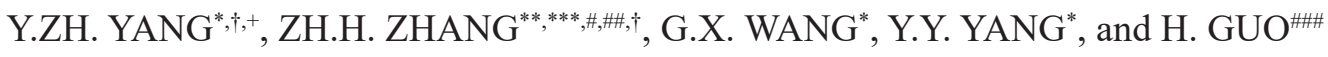 \\ School of Life Sciences, Zhengzhou Normal University, Zhengzhou, 450044 Henan, China* \\ Xinjiang Institute of Ecology and Geography, Chinese Academy of Sciences, Urumqi, 830011 Xinjiang, China ** \\ University of Chinese Academy of Sciences, 100049 Beijing, China ${ }^{* * * *}$ \\ Cele National Station of Observation and Research for Desert-Grassland Ecosystems in Xinjiang, Cele, \\ 848300 Xinjiang, China \\ Key Laboratory of Biogeography and Bio-resource in Arid Zone, Chinese Academy of Sciences, Urumqi, \\ 830011 Xinjiang, China ${ }^{\# \#}$ \\ School of Life Sciences, Xinjiang Normal University, Urumqi, 830054 Xinjiang, China ${ }^{\# \#}$
}

\begin{abstract}
Paeonia ostii T. Hong \& J.X. Zhang, an emerging oil crop, was intercropped with 3-year-old plantations of pawpaw [Chaenomeles sinensis (Thouin.) Koehne], Chinese toon (Toona sinensis Roem.), and walnut (Juglans regia L.). In order to achieve a better production system, we studied the effects of intercropping on the photosynthesis, growth, and yield of $P$. ostii. The results showed that different pattern of agroforestry systems changed microclimatic and growing site conditions in comparison to the control treatment. The correlation analysis demonstrated that both similarities and differences were found in relationship between net photosynthetic rate $\left(P_{\mathrm{N}}\right)$ and main ecophysiological factors at different treatments. Agroforestry systems significantly reduced transpiration rate and increased water-use efficiency (WUE), maximal quantum yield of PSII photochemistry, chlorophyll (Chl) $a$ and total $\mathrm{Chl}$ contents, whereas there were no differences between $P_{\mathrm{N}}$, intercellular $\mathrm{CO}_{2}$ concentration, photochemical efficiency of PSII in the light, and plant height in these systems. The obviously exponential relationship between $P_{\mathrm{N}}$ and PAR during a day were observed in Chinese toon and walnut treatments. The highest effective quantum yield of PSII photochemistry, electron transport rate, and photochemical quenching coefficient were observed in walnut treatment. The higher WUE and SPAD value, the thinnest stem, the biggest crown, the lowest stomatal conductance, and Chl $a / b$ ratio as well as the fewest pods and harvest seed yield were observed in pawpaw treatment. In addition, there was a significant correlation between SPAD value and Chl $(a+b)$ of $P$. ostii in agroforestry system. This study could be an important contribution for the science of land management in oil peony and other understory crops.
\end{abstract}

Additional key words: intercropping systems; land management; morphological traits; photosynthetic characteristics.

\section{Introduction}

With the rapid development of Chinese economy and constant improvement of living level, problem of feeding the population has been basically solved, whereas fats and oils are more demanding than ever before. Consequently, researchers have targeted plant sources to explore their uses and functional properties with the goal of developing improved varieties of edible oils that can withstand future challenges (Cheng et al. 2016).

Paeonia ostii T. Hong \& J.X. Zhang (Paeoniaceae), as an emerging oil crop, has a high potential in the production of oil. The plant is a perennial hardy shrub widely distributed in Henan and Anhui provinces of China. P. ostii is the parent of two medicinal varieties of tree peonies, namely, 'Feng Dan Bai' (Phoenix White) and 'Feng Dan

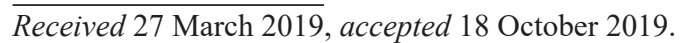

${ }^{+}$Corresponding author; phone: +86 13526511638, e-mail: yzhyang@163.com

Abbreviations: $C_{\mathrm{a}}-\mathrm{CO}_{2}$ concentration in air; $\mathrm{Chl}$ - chlorophyll; $C_{\mathrm{i}}-$ intercellular $\mathrm{CO}_{2}$ concentration; $E$ - transpiration rate; ETR - electron transport rate; $\mathrm{F}_{0}$ - minimal fluorescence yield of the dark-adapted state; $\mathrm{F}_{0}{ }^{\prime}$ - minimal fluorescence yield of the lightadapted state; $\mathrm{F}_{\mathrm{m}}$ - maximal fluorescence yield of the dark-adapted state; $\mathrm{F}_{\mathrm{m}}{ }^{\prime}$ - maximal fluorescence yield of the light-adapted state; $\mathrm{F}_{\mathrm{s}}$ - steady-state fluorescence yield; $\mathrm{F}_{\mathrm{v}} / \mathrm{F}_{\mathrm{m}}$ - maximal quantum yield of PSII photochemistry; $\mathrm{F}_{\mathrm{v}}{ }^{\prime} / \mathrm{F}_{\mathrm{m}}{ }^{\prime}-$ photochemical efficiency of PSII in the light; $g_{\mathrm{s}}$ - stomatal conductance; NPQ - nonphotochemical quenching; $P_{\mathrm{N}}$ - net photosynthetic rate; $\mathrm{q}_{\mathrm{P}}-$ photochemical quenching coefficient; $\mathrm{RH}$ - relative humidity; $\mathrm{T}_{\text {air }}$ - air temperature; $\mathrm{T}_{\text {leaf }}$ - leaf temperature; WUE - water-use efficiency $\left(=P_{\mathrm{N}} / E\right)$; $\Phi_{\text {PSII }}$ - effective quantum yield of PSII photochemistry.

Acknowledgements: This project was supported by the Sci-Tech Project of Henan Province (182102310655) and the Plan of Scientific Research Innovation Team of Zhengzhou Normal University.

${ }^{\dagger}$ Authors contributed equally to this work. 
Fen' (Phoenix Pink) which are grown for the bark of their roots, used as an antispasmodic throughout Asia (Surhone et al. 2010). Recently, the plant has been also recognized as underutilized woody oil-seed plant with a considerable potential for edible oil production. Compared to established oil crops, this plant presents a competitive agronomic performance, because the plant has a higher seed yield and unsaturated fatty acid content, especially of the $\alpha$-linolenic acid, essential for human life (Kim et al. 2014, Yang et al. 2017). Moreover, seed oil of P. ostii is the versatile oil and is not limited to food, but widely used in oleochemicals, cosmetics, and pharmaceuticals (Han et al. 2014). In 2011, peony was approved as the new edible seed oil by the Ministry of Health in China. Development of peony oil tree planting contributes to meet increasing demand for fats and oils and holds future challenges, such as climate change, sustainability, and food security (Peng et al. 2017). This species is propagated by seeds and its seedling stage takes two years from sowing to planting. Vegetative growth is dominant at the juvenile stage and continues from $3^{\text {rd }}$ to $5^{\text {th }}$ year of its growth. Since only few flowers and fruits develop at that time and rows become full of weeds, substantial benefit from the plantation is negligible during this period. In addition, wild $P$. ostii is distributed under forest cover and is a shade-tolerant species (Hong et al. 2004, Tang et al. 2017). Therefore, agroforestry can offer a convenient strategy for promoting its cultivation and conservation.

Agroforestry, a multifunctional working landscape, can be a viable land-use option that, in addition to alleviating poverty, offers a number of ecosystem services and environmental benefits (Jose 2009). Obvious 'midday depression of photosynthesis' of $P$. ostii was observed in monoculture systems at noon, especially in summer, whereas moderate shading treatment could relieve effectively this phenomenon and improve the yield (Bi et al. 2011, Tang et al. 2017, Han et al. 2018). Previous studies also suggested that the forest margin and forest gap with appropriate shade were the most suitable growing environment for oil tree peony (Zhou et al. 2010, Zhang et al. 2014). Shade trees could reduce the stress by ameliorating adverse climatic conditions and nutritional imbalances, while they may compete for growth resources (Beer et al. 1997). With these potential benefits for treebased agroforestry systems in mind, in order to maximize the potential benefits of crop, the reasonable choice of shade trees could avoid competitive interactions between trees and crops for nutrients, moisture, and light. Although many studies on P. ostii in tree-based agroforestry systems have been carried out in recent years, the results mainly focused on cultivation techniques and cost-benefit analysis (Xiang and Zhu 2016, Xu et al. 2017). There were few data available regarding the physiological and ecological characteristics and their relationship within agroforestry systems in summer that is the fruit developing and mature phase of this species. Considering the long-term history of cultivation in China, the objective of the present research was to study the $P$. ostii intercropping with trees of other species in order to achieve a better production system.

\section{Materials and methods}

Plant materials and site description: This study was conducted in July 2017 in an open experimental field (0.25 ha in area, $34^{\circ} 55^{\prime} 25^{\prime \prime} \mathrm{N}, 113^{\circ} 37^{\prime} 36^{\prime \prime} \mathrm{E}, 100 \mathrm{~m}$ a.s.1.) located in Zhengzhou the Yellow River National Wetland Nature Protection Zone, Zhengzhou, Henan Province, China. The typical north temperate continental monsoon climate of this region produces hot rainy summer, cold dry winter, and four distinct seasons. Mean annual temperature is $14.3^{\circ} \mathrm{C}$ and the annual mean rainfall is $640.9 \mathrm{~mm}$. The average frost-free period is approximately $209 \mathrm{~d}$ and the mean annual light time is $2,400 \mathrm{~h}$. The soil type of study area is sandy barren soil. The top soil layer $(0-20 \mathrm{~cm})$ at the studied field contained $5.10 \%$ total organic matter and $37.65 \mathrm{mg}$ (available nitrogen) $\mathrm{kg}^{-1}$. In the experimental fields, $0.06 \mathrm{~kg} \mathrm{~m}^{-2}$ of compound fertilizer $\left(\mathrm{NH}_{4} \mathrm{H}_{2} \mathrm{PO}_{4}\right)$ was applied for all treatments on 20 March (before florescence), 20 May (after florescence), and 20 September (abscission period) every year, respectively, and an irrigation followed. Otherwise, water came mainly from precipitation.

In the experiment, 2-year-old oil tree peony ( $P$. ostii) cultivated seedlings, 'Feng Dan Bai', were transplanted in the field in October 2013. Three indigenous tree species, pawpaw [Chaenomeles sinensis (Thouin.) Koehne], Chinese toon (Toona sinensis Roem.), and walnut (Juglans regia L.), were planted in the spring 2014, with a row spacing of $3 \mathrm{~m}$ and between row spacing of $3 \mathrm{~m}$. The tree rows were oriented north-south. Buffering zones, $5 \mathrm{~m}$ wide of $P$. ostii monoculture, were set between two treatments. $P$. ostii monoculture was considered as the control material during the experiment. $P$. ostii was planted at spacing of $0.4 \mathrm{~m}$ within rows and $0.5 \mathrm{~m}$ between rows of each treatment (pawpaw, Chinese toon, walnut, and control treat-

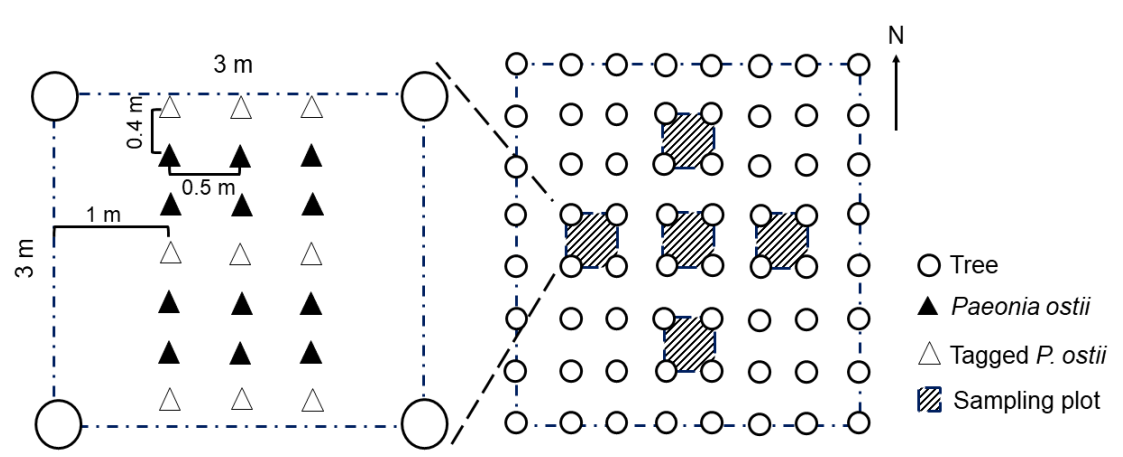

Fig. 1. Location of sampling plots (shaded boxes), trees (circle), Paeonia ostii (filled triangle), and tagged Paeonia ostii (unfilled triangle) between rows of trees. 
ments). Nine tagged $P$. ostii plants in each sampling plot were research objects (Fig. 1). At each time of sampling, a single leaf from the upper $P$. ostii canopy was used.

In order to harvest the fresh young leaves and shoots of Chinese toon next spring, coppice management was carried out every winter. We pruned pawpaw and walnut trees every spring to promote the formation of flower buds. The characteristics of selected pawpaw, Chinese toon, and walnut trees intercropped with oil tree peony were variable. In general, the walnut trees were taller and had the thicker stem diameter than that of the pawpaw trees and Chinese toon trees (Table 1S, supplement). Crown dimensions also differed for the three species, with live crown depths and crown widths of walnut trees being greater than those of Chinese toon and pawpaw trees. The crown of Chinese toon trees was closer to the ground.

Leaf gas exchange and chlorophyll (Chl) fluorescence parameters: The portable photosynthesis system ( $L I$ 6400XT, LI-COR Inc., Lincoln, NE, USA) was used to determine the net photosynthetic rate $\left(P_{\mathrm{N}}\right)$, transpiration rate $(E)$, stomatal conductance $\left(g_{\mathrm{s}}\right)$, and intercellular $\mathrm{CO}_{2}$ concentration $\left(C_{\mathrm{i}}\right)$ of $P$. ostii upper leaves. The water-use efficiency (WUE) was obtained by the ratio of $P_{\mathrm{N}}$ to $E$. PAR, air temperature $\left(\mathrm{T}_{\text {air }}\right)$, leaf temperature $\left(\mathrm{T}_{\text {leaf }}\right)$, relative air humidity $(\mathrm{RH})$, and $\mathrm{CO}_{2}$ concentration in air $\left(C_{\mathrm{a}}\right)$ were also measured concurrently with the quantum sensor, thermistors, $\mathrm{H}_{2} \mathrm{O}$ analyzer, and $\mathrm{CO}_{2}$ analyzer present on the LI-6400XT photosynthesis system. The diurnal photosynthetic course was measured from 8:00 to $18: 00$ $\mathrm{h}$ with 1-h interval during three successive sunny days in middle of July.

Parameters of $\mathrm{Chl}$ fluorescence of $P$. ostii upper leaves were measured via a pulse-amplitude modulated (PAM) fluorometer ( $\mathrm{Li}-6400 X \mathrm{XT}$ with 6400-40 fluorescence leaf chamber, LI-COR Inc., Lincoln, NE, USA) during successive sunny days from 9:00 to 11:00 h in July. Initial fluorescence $\left(\mathrm{F}_{0}\right)$ and maximal fluorescence $\left(\mathrm{F}_{\mathrm{m}}\right)$ were determined after 30-min dark adaptation at open air temperatures. The maximum photochemical efficiency of PSII $\left(\mathrm{F}_{\mathrm{v}} / \mathrm{F}_{\mathrm{m}}\right)$ was calculated as $\mathrm{F}_{\mathrm{v}} / \mathrm{F}_{\mathrm{m}}=\left(\mathrm{F}_{\mathrm{m}}-\mathrm{F}_{0}\right) / \mathrm{F}_{\mathrm{m}}$. The minimum fluorescence in the light $\left(\mathrm{F}_{0}{ }^{\prime}\right)$, maximum fluorescence $\left(\mathrm{F}_{\mathrm{m}}{ }^{\prime}\right)$ in the light and steady-state fluorescence $\left(\mathrm{F}_{\mathrm{s}}\right)$ were determined after being adapted by more than 30-min PPFD of $1,200 \mu \mathrm{mol} \mathrm{m} \mathrm{m}^{-2} \cdot \mathrm{s}^{-1}$. The photochemical efficiency of PSII in the light $\left(\mathrm{F}_{\mathrm{v}}{ }^{\prime} / \mathrm{F}_{\mathrm{m}}{ }^{\prime}\right)$, actual photochemical efficiency of PSII in the light $\left(\Phi_{\mathrm{PSII}}\right)$, electron transport rate (ETR), photochemical $\left(\mathrm{q}_{\mathrm{p}}\right)$, and nonphotochemical quenching coefficients (NPQ) were calculated based on the respective equations: $\mathrm{F}_{\mathrm{v}}{ }^{\prime} / \mathrm{F}_{\mathrm{m}}{ }^{\prime}=\left(\mathrm{F}_{\mathrm{m}}{ }^{\prime}-\mathrm{F}_{0}{ }^{\prime}\right) / \mathrm{F}_{\mathrm{m}}{ }^{\prime} ; \Phi_{\mathrm{PSII}}=$ $\left(\mathrm{F}_{\mathrm{m}}{ }^{\prime}-\mathrm{F}_{\mathrm{s}}\right) / \mathrm{F}_{\mathrm{m}}{ }^{\prime} ; \mathrm{ETR}=\mathrm{PPFD} \times \Phi_{\mathrm{PSII}} \times 0.85 \times 0.5 ; \mathrm{q}_{\mathrm{p}}=$ $\left(\mathrm{F}_{\mathrm{m}}{ }^{\prime}-\mathrm{F}_{\mathrm{s}}\right) /\left(\mathrm{F}_{\mathrm{m}}{ }^{\prime}-\mathrm{F}_{0}\right), \mathrm{NPQ}=\left(\mathrm{F}_{\mathrm{m}}-\mathrm{F}_{\mathrm{m}}{ }^{\prime}\right) / \mathrm{F}_{\mathrm{m}}{ }^{\prime}$.

Chl pigments and SPAD value: Chl concentration of upper leaves was estimated by biochemical methods (Arnon 1949) using $1 \mathrm{~g}$ of finely cut fresh leaves collected in midJuly. The sample was ground to a fine pulp with the help of a mortar and pestle and $20 \mathrm{~mL}$ of $80 \%$ acetone was added to it. This paste was centrifuged for $5 \mathrm{~min}$ at 5,000 rpm. The supernatant was transferred to a $50-\mathrm{mL}$ beaker. The residue was then ground again with $20 \mathrm{~mL}$ of $80 \%$ acetone, centrifuged for $5 \mathrm{~min}$ at 5,000 rpm and the supernatant was transferred to the same beaker. The mortar and pestle were washed with $80 \%$ acetone and the clear washing were collected in the beaker. The volume was made up to $100 \mathrm{~mL}$ by adding extra $80 \%$ acetone. This was repeated for all the leaf samples. The absorbance (Hitachi U-1900 UV-Vis Ratio Beam, Hitachi High Technologies, Japan) of the extract solutions was read at 645 and $663 \mathrm{~nm}$ against the solvent ( $80 \%$ acetone) as blank. Pigment concentrations were calculated using the following equations:

Chl $a=12.7 \mathrm{~A}_{643}-2.69 \mathrm{~A}_{645}, \mathrm{Chl} b=22.9 \mathrm{~A}_{645}-4.68 \mathrm{~A}_{663}$. $\mathrm{A}=$ absorbance at specific wavelengths.

The portable chlorophyll meter SPAD 502 (Konica Minolta Sensing, Inc., Japan) measurements were performed on tagged leaves to estimate foliar $\mathrm{Chl}$ and total nitrogen $(\mathrm{N})$ status.

Growth and yield: The stem diameter at $10 \mathrm{~cm}$ above the ground, plant height (from ground to the highest leaf), and crown width (mean diameter of crown) of P. ostii were measured with the help of a measuring tape and the number of pod per plant was counted in July. At maturity, early August, seed yield of every treatment was harvested. The harvested seeds were shade-dried for $30 \mathrm{~d}$ and then 1,000 -seed mass and yield per ha were measured.

Statistical analysis and mapping: Statistical analyses were made using the SPSS v. 20 software package. One-way analysis of variance (ANOVA) was used to test averages. Significant differences between treatments means were accessed using Tukey's HSD at $P<0.05$. Correlation analysis was evaluated at $P<0.05$ and $P<0.01$. All measurements shown were the mean \pm standard deviation (SD). All maps were generated by using OriginPro v. 8.0.

\section{Results}

Diurnal variation of PAR and $\mathrm{T}_{\text {air }}$ in the different treatments was shown in Fig. 1S (supplement). A similar diurnal variation of $\mathrm{T}_{\text {air }}$ was observed in all treatments. A similar diurnal variation of PAR was also observed in all treatments, except pawpaw treatment that showed an obvious decrease at 11:00 $\mathrm{h}$ followed by an increase, and PAR dropped rapidly from 13:00 to 17:00 $\mathrm{h}$ in all treatments.

For daily averages of main environmental factors, control and walnut treatments showed higher $\mathrm{T}_{\text {air }}$ and $\mathrm{T}_{\text {leaf }}$ than other treatments (Table 1). The lowest $C_{\mathrm{a}}$ was observed in the control treatment, while the highest $C_{\mathrm{a}}$ in walnut treatment. RH in Chinese toon and walnut treatments were higher than that in the other treatments. The total solar radiation reaching the upper parts of $P$. ostii canopies in different agroforestry systems was lower than that in the control treatment. In comparison with control treatment, pawpaw tree canopies incepted $46.6 \%$ of PAR.

The daily averages of leaf gas-exchange parameters of $P$. ostii in July by different treatments were shown in Table 1. Treatment differences for $P_{\mathrm{N}}$ and $C_{\mathrm{i}}$ were not observed. The $g_{\mathrm{s}}$ in pawpaw treatment was the lowest, 
Table 1. Treatment differences for daily averages of leaf gas exchange and environmental parameters of control, pawpaw, Chinese toon, and walnut plots. Values are means $\pm \mathrm{SD}, n=45$. The same letters indicate no significant differences $(P<0.05)$ according to Tukey's test. $C_{\mathrm{a}}-\mathrm{CO}_{2}$ concentration in air; $C_{\mathrm{i}}-$ intercellular $\mathrm{CO}_{2}$ concentration; $E$ - transpiration rate; $g_{\mathrm{s}}-$ stomatal conductance; $P_{\mathrm{N}}-$ net photosynthetic rate; $\mathrm{RH}$ - relative humidity; $\mathrm{T}_{\text {air }}$ - air temperature; $\mathrm{T}_{\text {leaf }}$ - leaf temperature; WUE - water-use efficiency.

\begin{tabular}{lllll}
\hline Parameter & Control & Pawpaw & Chinese toon & Walnut \\
\hline $\mathrm{T}_{\text {air }}\left[{ }^{\circ} \mathrm{C}\right]$ & $34.91 \pm 0.20^{\mathrm{a}}$ & $33.86 \pm 0.14^{\mathrm{b}}$ & $33.24 \pm 0.17^{\mathrm{c}}$ & $34.52 \pm 0.12^{\mathrm{a}}$ \\
$\mathrm{T}_{\text {leaf }}\left[{ }^{\circ} \mathrm{C}\right]$ & $34.66 \pm 0.25^{\mathrm{a}}$ & $33.73 \pm 0.17^{\mathrm{b}}$ & $33.48 \pm 0.19^{\mathrm{b}}$ & $34.58 \pm 0.19^{\mathrm{a}}$ \\
$C_{\mathrm{a}}\left[\mu \mathrm{mol}\left(\mathrm{CO}_{2}\right) \mathrm{mol}^{-1}\right]$ & $399.33 \pm 1.34^{\mathrm{b}}$ & $401.06 \pm 1.08^{\mathrm{ab}}$ & $401.59 \pm 1.43^{\mathrm{ab}}$ & $404.36 \pm 0.76^{\mathrm{a}}$ \\
$\mathrm{RH}[\%]$ & $44.18 \pm 0.79^{\mathrm{b}}$ & $45.72 \pm 0.46 \mathrm{~b}$ & $49.96 \pm 0.60^{\mathrm{a}}$ & $49.29 \pm 0.75^{\mathrm{a}}$ \\
$\mathrm{PAR}\left[\mu \mathrm{mol}\left(\mathrm{photon}^{\mathrm{a}} \mathrm{m}^{-2} \mathrm{~s}^{-1}\right]\right.$ & $1,303.51 \pm 64.42^{\mathrm{a}}$ & $696.21 \pm 73.76^{\mathrm{c}}$ & $1,069.32 \pm 69.10^{\mathrm{b}}$ & $1,055.69 \pm 38.80^{\mathrm{b}}$ \\
$P_{\mathrm{N}}\left[\mu \mathrm{mol} \mathrm{m} \mathrm{s}^{-1}\right]$ & $9.84 \pm 0.30^{\mathrm{a}}$ & $9.54 \pm 0.54^{\mathrm{a}}$ & $9.86 \pm 0.41^{\mathrm{a}}$ & $10.10 \pm 0.51^{\mathrm{a}}$ \\
$g_{\mathrm{s}}\left[\mathrm{mol}\left(\mathrm{H}_{2} \mathrm{O}\right) \mathrm{m}^{-2} \mathrm{~s}^{-1}\right]$ & $0.20 \pm 0.01^{\mathrm{ab}}$ & $0.18 \pm 0.01^{\mathrm{b}}$ & $0.22 \pm 0.01^{\mathrm{a}}$ & $0.19 \pm 0.01^{\mathrm{ab}}$ \\
$C_{\mathrm{i}}\left[\mu \mathrm{mol}\left(\mathrm{CO}_{2}\right) \mathrm{mol}^{-1}\right]$ & $285.70 \pm 3.59^{\mathrm{a}}$ & $287.20 \pm 4.22^{\mathrm{a}}$ & $294.81 \pm 2.87^{\mathrm{a}}$ & $285.78 \pm 5.53^{\mathrm{a}}$ \\
$E\left[\mathrm{mmol}\left(\mathrm{H}_{2} \mathrm{O}\right) \mathrm{m}^{-2} \mathrm{~s}^{-1}\right]$ & $5.37 \pm 0.27^{\mathrm{a}}$ & $4.19 \pm 0.16^{\mathrm{b}}$ & $4.24 \pm 0.22^{\mathrm{b}}$ & $4.37 \pm 0.17^{\mathrm{b}}$ \\
$\mathrm{WUE}\left[\mu \mathrm{mol}\left(\mathrm{CO}_{2}\right) \mathrm{mmol}^{\mathrm{a}}\left(\mathrm{H}_{2} \mathrm{O}\right)^{-1}\right]$ & $1.93 \pm 0.06^{\mathrm{c}}$ & $2.47 \pm 0.09^{\mathrm{a}}$ & $2.20 \pm 0.08^{\mathrm{b}}$ & $2.37 \pm 0.14^{\mathrm{a}}$ \\
\hline
\end{tabular}

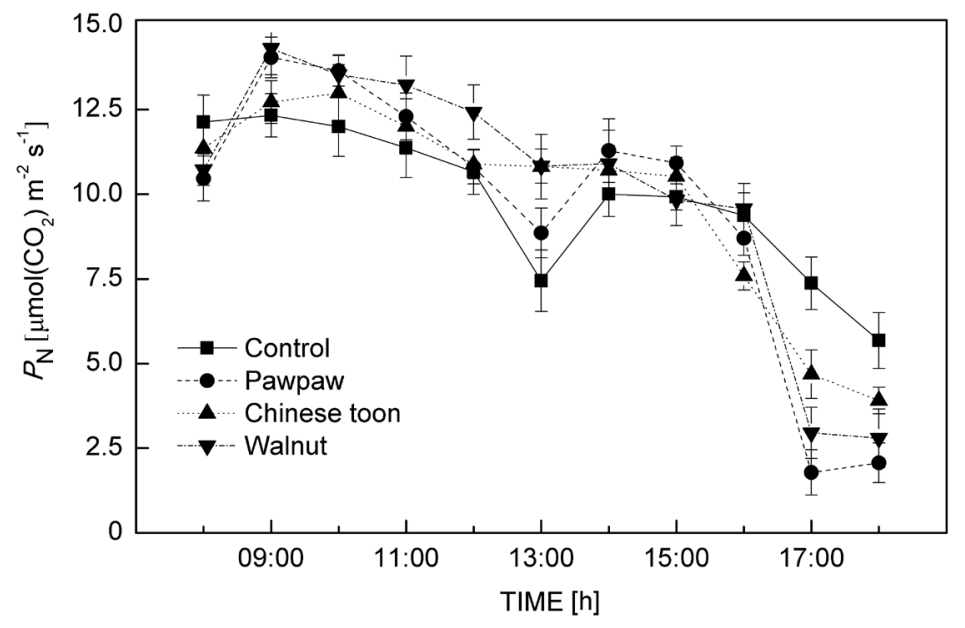

Fig. 2. Diurnal variation of net photosynthetic rate $\left(P_{\mathrm{N}}\right)$ of Paeonia ostii for control, pawpaw, Chinese toon, and walnut plots. Vertical bars represent SD $(n=45)$. while that in Chinese toon treatment was the highest. The significant differences for $E$ were between control and the other treatments, and higher WUE was observed in walnut treatment. The effect of different treatments on the diurnal variation of $P$. ostii $P_{\mathrm{N}}$ was divided into two situations (Fig. 2). Diurnal variation of $P_{\mathrm{N}}$ of $P$. ostii was found for control, pawpaw, Chinese toon, and walnut plots. Unimodal curves were observed in Chinese toon and walnut treatments, while bimodal curves were observed in control and pawpaw treatments. $P_{\mathrm{N}}$ of $P$. ostii in Chinese toon and walnut treatments did not show obvious 'midday depression of photosynthesis', while the phenomenon was observed in control and pawpaw treatments between 12:00 and 14:00 h.

The obviously exponential relationship between $P_{\mathrm{N}}$ and PAR during a day were observed in Chinese toon and walnut treatments (Fig. 3). However, the range of $P_{\mathrm{N}}$ in pawpaw and monoculture treatments was narrow throughout the day except for a few outliers in pawpaw treatment, where its $P_{\mathrm{N}}$ was more concentrated in the range of $8-16 \mu \mathrm{mol} \mathrm{m} \mathrm{m}^{-2} \mathrm{~s}^{-1}$ and PAR was below 1,600 $\mu \mathrm{mol}\left(\right.$ photon) $\mathrm{m}^{-2} \mathrm{~s}^{-1}$.

The parameters of $\mathrm{Chl}$ fluorescence under different treatments in July were summarized in Table 2. $\mathrm{F}_{\mathrm{v}} / \mathrm{F}_{\mathrm{m}}$ illustrated a difference between control and the other treatments, while no difference was found for $F_{v}{ }^{\prime} / F_{m}{ }^{\prime}$ in all treatments. The $\Phi_{\mathrm{PSII}}, \mathrm{ETR}, \mathrm{q}_{\mathrm{P}}$, and NPQ value in control treatment was lower than that of intercropping systems. In comparison with monoculture and walnut intercropping system, pawpaw and Chinese toon intercropping systems significantly improved $\mathrm{Chl} a, b, \mathrm{Chl}(a+b)$ contents, and SPAD value of $P$. ostii leaves. The lowest $\mathrm{Chl} a / b$ ratio was observed in the pawpaw treatment.

Correlation analysis of $P$. ostii $P_{\mathrm{N}}$ and environmental or physiological parameters was presented in Table 3. PAR and $g_{\mathrm{s}}$ positively correlated with $P_{\mathrm{N}}$ in all treatments. $C_{\mathrm{i}}$ and $\mathrm{T}_{\text {leaf }}$ showed highly significant negative and positive correlation with $P_{\mathrm{N}}$ in agroforestry systems, respectively. $E$ and $\mathrm{T}_{\text {air }}$ had no correlation with $P_{\mathrm{N}}$ in Chinese toon treatment. The highly significant correlation between WUE and $P_{\mathrm{N}}$ was observed in pawpaw and walnut treatments. $\mathrm{RH}$ in pawpaw treatment had significantly negative correlation with $P_{\mathrm{N}}$. However, $C_{\mathrm{a}}$ and ETR had no correlation with $P_{\mathrm{N}}$ in any treatment.

Table 4 showed the relationship of SPAD value and Chl content. Chl $(a+b)$ showed significant positive correlation with SPAD value in agroforestry systems, while the negative correlation in control. 
The stem diameter, $10 \mathrm{~cm}$ above ground, in pawpaw treatment was lower than that of the other treatments, while pawpaw treatment showed the biggest crown width (Table 5). Plant height did not show any difference for all the treatments. Compared to pawpaw intercropping treatment, Chinese toon and walnut treatments significantly increased pod number per plant. In addition, 1,000-seed mass in Chinese toon and walnut treatments was 11.0 and $5.0 \%$ higher than that of the control, respectively. Seed yield per ha in Chinese toon and walnut treatments was 54.5 and $18.9 \%$ higher than that of control, respectively. However, 1000-seed mass and seed yield in pawpaw

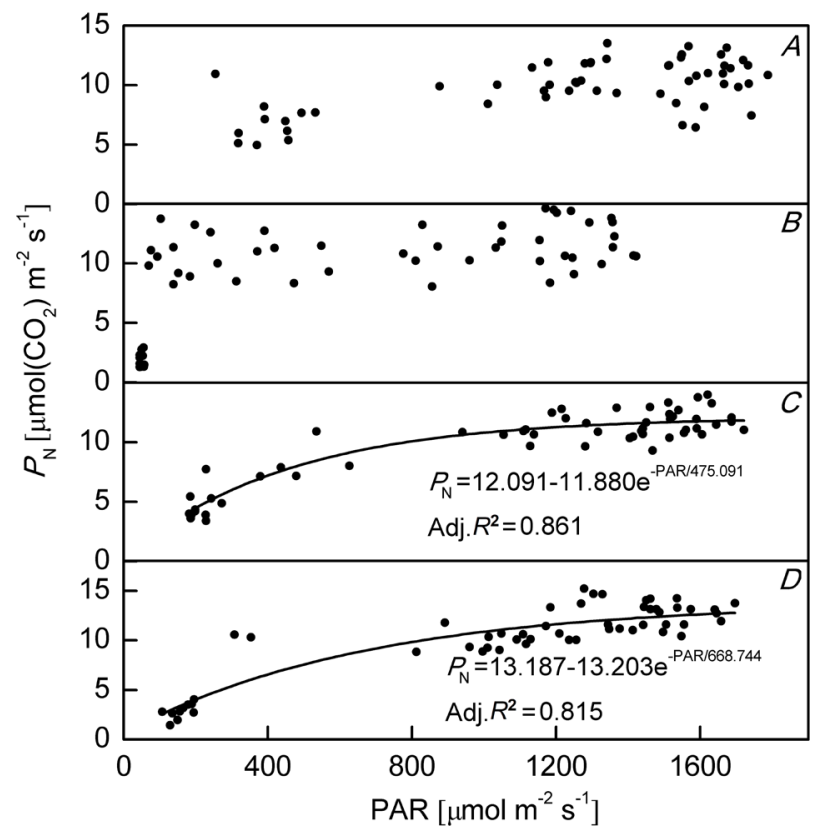

Fig. 3. The relationship between net photosynthetic rate $\left(P_{\mathrm{N}}\right)$ and photosynthetically active radiation (PAR) for control $(A)$, pawpaw $(B)$, Chinese toon $(C)$, and walnut $(D)$ plots. Lines describe the exponential relationship between $P_{\mathrm{N}}$ and PAR. Values are from four treatments $(n=55)$. treatment significantly decreased by 8.5 and $63.3 \%$ in comparison with control treatment, respectively.

\section{Discussion}

Agroforestry system is a sustainable agricultural practice for highly efficient utilization of resources and can provide a suitable environment for crops. Land management by intercropping of crops has been extensively studied. The coffee, millet, and soybean farmers have benefited from this kind of land management (Perfecto et al. 1996, Sanou et al. 2012, Araújo et al. 2015, Nasielski et al. 2015). This land management is valid also for the cultivation of oil tree peony.

In situ patterns of leaf-level photosynthesis were created by interactions between an optimum ambient environmental conditions and the species-specific sensitivity to these combined factors (Braatne and Bliss 1999). The correlation analysis in this study showed that both similarities and differences were found in relationship between $P_{\mathrm{N}}$ and ecophysiological factors (Table 3 ). In all treatments, PAR and $g_{s}$ positively and significantly correlated with $P_{\mathrm{N}}$, while $C_{\mathrm{a}}$ did not show any correlation with $P_{\mathrm{N}}$, indicating that environmental conditions may be similar surrounding the study species, but the photosynthetic responses of the species are different $(\mathrm{Wu}$ et al. 2011).

Economically, the results showed benefits and drawbacks of $P$. ostii grown in agroforestry systems in summer. The major benefits can be placed into two main categories, both associated with a reduced stress for the plant. Amelioration of microclimatic and site conditions, such as reduced $\mathrm{T}_{\text {air }}$, PAR, and higher $\mathrm{RH}$, promoted the morphological and physiological changes of $P$. ostii and increased the seed yield. Moderate shade within agroforestry systems can improve the efficiency of utilization of resources and microclimatic conditions within the systems, contributing to an overall high biomass production (Xue et al. 2008, Freese et al. 2010,

Table 2. Fluorescence parameters, chlorophyll contents, and SPAD value of Paeonia ostii in control, pawpaw, Chinese toon, and walnut plots. Values are means $\pm \mathrm{SD}, n=45$. The same letters indicate no significant differences $(P<0.05)$ according to the Tukey's test. $\mathrm{Chl}$ - chlorophyll; ETR - electron transport rate; $\mathrm{F}_{\mathrm{v}} / \mathrm{F}_{\mathrm{m}}$ - maximal quantum yield of PSII photochemistry; $\mathrm{F}_{\mathrm{v}}{ }^{\prime} / \mathrm{F}_{\mathrm{m}}{ }^{\prime}-$ photochemical efficiency of PSII in the light; NPQ - nonphotochemical quenching; $\mathrm{q}_{\mathrm{p}}$ - photochemical quenching coefficient; $\Phi_{\mathrm{PSII}}-$ effective quantum yield of PSII photochemistry.

\begin{tabular}{lllll}
\hline Parameter & Control & Pawpaw & Chinese toon & Walnut \\
\hline $\mathrm{F}_{\mathrm{v}} / \mathrm{F}_{\mathrm{m}}$ & $0.75 \pm 0.01^{\mathrm{b}}$ & $0.79 \pm 0.01^{\mathrm{a}}$ & $0.80 \pm 0.04^{\mathrm{a}}$ & $0.79 \pm 0.01^{\mathrm{a}}$ \\
$\mathrm{F}_{\mathrm{v}} / \mathrm{F}_{\mathrm{m}}{ }^{\prime}$ & $0.45 \pm 0.02^{\mathrm{a}}$ & $0.47 \pm 0.03^{\mathrm{a}}$ & $0.46 \pm 0.04^{\mathrm{a}}$ & $0.48 \pm 0.02^{\mathrm{a}}$ \\
$\Phi_{\mathrm{PSII}}$ & $0.29 \pm 0.01^{\mathrm{b}}$ & $0.32 \pm 0.03^{\mathrm{ab}}$ & $0.30 \pm 0.03^{\mathrm{ab}}$ & $0.33 \pm 0.023^{\mathrm{a}}$ \\
$\mathrm{ETR}$ & $121.41 \pm 5.31^{\mathrm{b}}$ & $133.91 \pm 12.39^{\mathrm{ab}}$ & $127.29 \pm 13.91^{\mathrm{ab}}$ & $141.67 \pm 12.73^{\mathrm{a}}$ \\
$\mathrm{q}_{\mathrm{P}}$ & $0.64 \pm 0.02^{\mathrm{b}}$ & $0.67 \pm 0.01^{\mathrm{ab}}$ & $0.65 \pm 0.02^{\mathrm{b}}$ & $0.69 \pm 0.03^{\mathrm{a}}$ \\
$\mathrm{NPQ}$ & $1.60 \pm 0.19^{\mathrm{b}}$ & $1.74 \pm 0.08^{\mathrm{ab}}$ & $2.21 \pm 0.16^{\mathrm{a}}$ & $2.11 \pm 0.40^{\mathrm{a}}$ \\
$\mathrm{Chl} a\left[\mathrm{mg} \mathrm{g}^{-1}(\mathrm{FM})\right]$ & $1.03 \pm 0.01^{\mathrm{c}}$ & $1.46 \pm 0.03^{\mathrm{a}}$ & $1.46 \pm 0.02^{\mathrm{a}}$ & $1.18 \pm 0.04^{\mathrm{b}}$ \\
$\mathrm{Chl} b\left[\mathrm{mg} \mathrm{g}^{-1}(\mathrm{FM})\right]$ & $0.45 \pm 0.01^{\mathrm{b}}$ & $0.65 \pm 0.01^{\mathrm{a}}$ & $0.63 \pm 0.01^{\mathrm{a}}$ & $0.46 \pm 0.04^{\mathrm{b}}$ \\
$\mathrm{Chl}(a+b)\left[\mathrm{mg} \mathrm{g}^{-1}(\mathrm{FM})\right]$ & $1.47 \pm 0.01^{\mathrm{c}}$ & $2.11 \pm 0.04^{\mathrm{a}}$ & $2.09 \pm 0.03^{\mathrm{a}}$ & $1.63 \pm 0.06^{\mathrm{b}}$ \\
$\mathrm{Chl} a / b$ ratio & $2.29 \pm 0.03^{\mathrm{b}}$ & $2.23 \pm 0.06^{\mathrm{c}}$ & $2.32 \pm 0.02^{\mathrm{b}}$ & $2.76 \pm 0.29^{\mathrm{a}}$ \\
$\mathrm{SPAD}$ value & $45.67 \pm 1.23^{\mathrm{b}}$ & $57.73 \pm 1.46^{\mathrm{a}}$ & $54.60 \pm 1.50^{\mathrm{a}}$ & $51.76 \pm 0.90^{\mathrm{b}}$ \\
\hline
\end{tabular}


Table 3. Correlation coefficients $\left(R^{2}\right)$ for net photosynthetic rate $\left(P_{\mathrm{N}}\right)$ and environmental or physiological parameters of Paeonia ostii in control, pawpaw, Chinese toon, and walnut plots. ${ }^{*}{ }^{* *}$ - significant at $P<0.05$ and $P<0.01$, respectively; ns not significant; df $(n=55)$. $C_{\mathrm{i}}-$ intercellular $\mathrm{CO}_{2}$ concentration; $E$ - transpiration rate; ETR - electron transport rate; $g_{\mathrm{s}}-$ stomatal conductance; RH - relative humidity; $\mathrm{T}_{\text {air }}$ - air temperature; $\mathrm{T}_{\text {leaf }}$ - leaf temperature; WUE - water-use efficiency.

\begin{tabular}{lrrcr}
\hline Parameter & Control & Pawpaw & Chinese toon & Walnut \\
\hline$g_{\mathrm{s}}$ & $0.684^{* *}$ & $0.880^{* *}$ & $0.802^{* *}$ & $0.519^{* *}$ \\
$C_{\mathrm{i}}$ & $-0.075^{\text {ns }}$ & $-0.695^{* *}$ & $-0.666^{* *}$ & $-0.766^{* *}$ \\
$E$ & $0.625^{* *}$ & $0.901^{* *}$ & $0.820^{\text {ns }}$ & $0.609^{* *}$ \\
$\mathrm{WUE}$ & $0.139^{\text {ns }}$ & $0.619^{* *}$ & $-0.039^{\text {ns }}$ & $0.626^{* *}$ \\
$\mathrm{~T}_{\text {air }}$ & $0.492^{* *}$ & $0.450^{* *}$ & $0.055^{\text {ns }}$ & $0.787^{* *}$ \\
$\mathrm{~T}_{\text {leaf }}$ & $0.105^{\text {ns }}$ & $0.594^{* *}$ & $0.849^{* *}$ & $0.834^{* *}$ \\
$C_{\text {a }}$ & $0.263^{\text {ns }}$ & $-0.063^{\text {ns }}$ & $-0.028^{\text {ns }}$ & $-0.078^{\text {ns }}$ \\
$\mathrm{RH}$ & $-0.076^{\text {ns }}$ & $-0.462^{* *}$ & $0.046^{\text {ns }}$ & $0.051^{\text {ns }}$ \\
PAR & $0.616^{* *}$ & $0.605^{* *}$ & $0.895^{* *}$ & $0.887^{* *}$ \\
ETR & $0.111^{\text {ns }}$ & $-0.092^{\text {ns }}$ & $0.065^{\text {ns }}$ & $0.119^{\text {ns }}$ \\
\hline
\end{tabular}

Table 4. Correlation of SPAD value and chlorophyll (Chl) content of Paeonia ostii in control, pawpaw, Chinese toon, and walnut plots. ${ }^{*},{ }^{* *}$ - significant at $P<0.05$ and $P<0.01$, respectively; ns - not significant; $\mathrm{df}(n=55)$.

\begin{tabular}{lcccc}
\hline Parameter & Control & Pawpaw & Chinese toon & Walnut \\
\hline Chl $a$ & $-0.523^{\text {ns }}$ & $0.603^{\text {ns }}$ & $0.635^{\text {ns }}$ & $0.538^{\text {ns }}$ \\
Chl $b$ & $-0.621^{\text {ns }}$ & $0.490^{\text {ns }}$ & $0.748^{*}$ & $0.664^{\text {ns }}$ \\
Chl $(a+b)$ & $-0.705^{*}$ & $0.668^{*}$ & $0.687^{*}$ & $0.753^{*}$ \\
Chl $a / b$ & $0.432^{\text {ns }}$ & $0.111^{\text {ns }}$ & $-0.658^{\text {ns }}$ & $-0.480^{\text {ns }}$ \\
\hline
\end{tabular}

Zhang et al. 2011). The morphological characteristics (e.g., thinner stem, bigger crown, and more green leaves) and yield indexes (e.g., the higher pod number per plant, 1,000-seed mass, and harvest seed yield) were observed in Chinese toon and walnut treatments in comparison to monoculture. It has indicated that the involved systems could lead to allometry and regulate the relationship of distributive proportion between sink and source of P. ostii (Cao and Ohkubo 1998, Wang et al. 2017). The Chl fluorescence can be used to evaluate changes in PSII photochemistry of leaves. The normal $F_{v} / F_{m}$ value, as the probe response to the extent of stress from environment, is in the range of $0.80-0.85$ under nonstress conditions, while it could significantly decrease under stressful conditions (Lichtenthaler et al. 2007). The higher values of $\mathrm{F}_{\mathrm{v}} / \mathrm{F}_{\mathrm{m}}$ were observed in agroforestry systems in comparison with the control treatment, indicating that photosynthesis of $P$. ostii was negatively influenced by full sunlight. The higher $\Phi_{\text {PSII }}$ and $\mathrm{q}_{\mathrm{p}}$ in agroforestry systems suggested that agroforestry systems could enhance the light capture efficiency, the actual photochemical efficiency of PSII, the activity of electron transfer, and the efficiency of heat dissipation for $P$. ostii leaves (Müller et al. 2001, Cai et al. 2016). Higher NPQ means that higher part of absorbed light energy is dissipated by protective mechanisms (Gilmore 1997). However, higher NPQ in this study is observed in agroforestry system indicating that light-utilization efficiency decreased in photosynthetic process, and the underlying reason remains to be explored.

Reduction in the quantity and quality of transmitted light can avoid over-burning. Strong light tends to induce $\mathrm{T}_{\text {air }}$ to rise and $\mathrm{RH}$ to drop, which can inhibit photosynthesis and may lead to photooxidative destruction of the photosynthetic apparatus (Powles 1984, Valladares and Pearcy 2010). Evidence showed that moderate shade treatment could relieve 'midday depression of photosynthesis' for understory plants (Zhang et al. 2015, Huang et al. 2018). In this study, the obviously decreased $P_{\mathrm{N}}$, which was observed in full sunlight at noon, was relieved in Chinese toon and walnut treatments. However, the reason why 'midday depression of photosynthesis' occurred in pawpaw treatments was different from the above, and it may be related to temporary decreased PAR at noon.

The main drawback was competition for light intensity in forest understory. The PAR in pawpaw, Chinese toon, and walnut treatments was $54.3,82.0$, and $81.0 \%$ of that in control treatment (full sunlight), respectively, but there was no significant difference in $P_{\mathrm{N}}$, especially for pawpaw treatment, where relatively stable light conditions maintained stable photosynthesis (Fig. 2). On the other hand, it might be because the understory plant species utilize high-light sunflecks, which significantly contribute to the percentage of total carbon gain (Pfitsch and Pearcy 1989). In addition, shade leaves were relatively enriched in $\mathrm{Chl} b$ and have the lowered $\mathrm{Chl} a / b$ ratio, which has been thought to be a chromatic adaptation to help balance the light absorption between the two photosystems (Anderson 1986, Adamson et al. 1991). In pawpaw treatment, the highest $\mathrm{Chl} a, b$, total $\mathrm{Chl}$ contents, and the lowest $\mathrm{Chl} a / b$

Table 5. Growth and yield indexes of Paeonia ostii in control, pawpaw, Chinese toon, and walnut plots. Values are means $\pm \mathrm{SD}, n=10$. The same letters indicate no significant differences $(P<0.05)$ according to the Tukey's test.

\begin{tabular}{|c|c|c|c|c|}
\hline Parameter & Control & Pawpaw & Chinese toon & Walnut \\
\hline Stem diameter $[\mathrm{cm}]$ & $1.66 \pm 0.05^{\mathrm{a}}$ & $1.11 \pm 0.03^{\mathrm{c}}$ & $1.58 \pm 0.06^{\mathrm{ab}}$ & $1.46 \pm 0.06^{\mathrm{b}}$ \\
\hline Plant height $[\mathrm{cm}]$ & $64.72 \pm 2.17^{\mathrm{a}}$ & $70.32 \pm 2.05^{\mathrm{a}}$ & $68.32 \pm 2.05^{\mathrm{a}}$ & $65.93 \pm 2.02^{\mathrm{a}}$ \\
\hline Crown width $[\mathrm{cm}]$ & $66.80 \pm 1.21^{\mathrm{b}}$ & $72.46 \pm 1.01^{\mathrm{a}}$ & $70.21 \pm 1.93^{\mathrm{ab}}$ & $67.65 \pm 0.98^{\mathrm{ab}}$ \\
\hline Pod number per plant & $2.57 \pm 0.23^{\mathrm{a}}$ & $0.70 \pm 0.12^{\mathrm{b}}$ & $2.93 \pm 0.24^{\mathrm{a}}$ & $2.67 \pm 0.31^{\mathrm{a}}$ \\
\hline 1,000 -seed mass $[\mathrm{g}]$ & $309.46 \pm 1.54^{\mathrm{c}}$ & $283.28 \pm 0.78^{\mathrm{d}}$ & $343.60 \pm 0.78^{\mathrm{a}}$ & $324.93 \pm 0.77^{b}$ \\
\hline Yield [kg ha-1] & $1,924.34 \pm 53.53^{\mathrm{c}}$ & $706.18 \pm 46.26^{\mathrm{d}}$ & $2,972.75 \pm 63.82^{a}$ & $2,287.94 \pm 46.33^{b}$ \\
\hline
\end{tabular}


ratio were observed. One could assume that the higher Chl content and suitable habitat are mainly responsible for the higher $P_{\mathrm{N}}$; however, this is not the case. The possible reason could be that the shade effect was more adverse on fruit yield than that on photosynthetic capability and flowering stage, indicating effects on bud differentiation and fruit set (Cai 2011). In addition, long-term exposure to shade may diminish reproductive potential directly by decreasing floral initiation (Cannell 1975, Pang et al. 2017). Therefore, it was concluded that the pod and fruit set can both be affected by shading, which can directly reduce crop yield even if all the other growth factors are favorable. Compared to the other control treatments, the fewer pod and lower seed yield were observed in pawpaw treatment, whereas the $P_{\mathrm{N}}$ did not show any difference. The effect of agroforestry systems on seed yield of oil tree peony is possibly due to several factors such as reduced photosynthesis, an imbalance of biomass allocation between reproductive growth (e.g., flower initiation) and vegetative growth, and other morphogenetic characteristics.

Monoculture and intercropping system provide distinct environmental factors affecting leaf pigment composition and content. Hand-held Chl meters, nondestructive methods for determining leaf $\mathrm{Chl}$ content, present advantages by allowing rapid and repeated measurements of the same leaves overtime. In this study, higher SPAD values were observed in agroforestry system (Table 2), and there was a significant correlation between SPAD value and Chl $(a+b)$ of $P$. ostii in agroforestry system (Table 4), which was consistent with Mielke et al. (2010). However, it also showed an opposite relationship in control indicating that the mathematical relationship between SPAD values and foliar pigment content varies with environmental growth conditions (Campbell et al. 1990).

Many factors can influence tree shading of adjoining agricultural crops within tree-based intercropping systems. Therefore, shade tree management (e.g., pruning, thinning, and/or replanting) is also essential to ensure the normal growth and development of understory plants. So further research on other aspects, e.g., allelopathy, soil organic matter, biological nitrogen fixation, and light availability of $P$. ostii within agroforestry systems are needed.

In summary, we found that there is a great potential for tree-based intercropping systems in Henan, a traditionally agricultural province of China, where $P$. ostii has long history of cultivation. Therefore, the study of the agroforestry system in Henan can play an important role in resolving the land contention between agriculture and forestry, increasing farmer's income, and promoting the sustainable and harmonious development between economy and environment. This study could be an important contribution to the science of land management in oil peony and other understory crops.

\section{References}

Adamson H.Y., Chow W.S., Anderson J.M. et al.: Photosynthetic acclimation of Tradescantia albiflora to growth irradiance: Morphological, ultrastructural, and growth responses. -
Physiol. Plantarum 82: 353-359, 1991.

Anderson J.M.: Photoregulation of the composition, function, and structure of thylakoid membranes. - Ann. Rev. Plant Physio. 37: 93-136, 1986.

Araújo A.V., Partelli F.L., Oliveira M.G. et al.: Microclimatic and vegetative growth in coffee and banana intercrop. - Coffee Sci. 10: 214-222, 2015.

Arnon D.I.: Copper enzymes in isolated chloroplasts. Polyphenoloxidase in Beta vulgaris. - Plant Physiol. 24: 1-15, 1949.

Beer J., Muschler R., Kass D., Somarriba E.: Shade management in coffee and cacao plantations. - Agroforest. Syst. 38: 139164, 1997.

Bi Y.W., Qin J., Wang K.L. et al.: [Photosynthetic characteristis of Paeonia ostii in different seasons.] - Tianjin Agric. Sci. 17: 18-21, 2011. [In Chinese]

Braatne J.H., Bliss L.C.: Comparative physiological ecology of lupines colonizing early successional habitats on Mount St. Helens. - Ecology 80: 891-907, 1999.

Cai Y.F., Li S.F., Wang J.H. et al.: [Effects of shading on growth and photosynthetic characteristics of oil peony.] - Acta Bot. Bor.-Occident. Sin. 36: 1623-1631, 2016. [In Chinese]

Cai Z.Q.: Shade delayed flowering and decreased photosynthesis, growth and yield of Sacha Inchi (Plukenetia volubilis) plants.Ind. Crop Prod. 34:1235-1237, 2011.

Campbell R.J., Mobley K.N., Marini R.P., Pfeiffer D.G.: Growing conditions alter the relationship between SPAD-501 values and apple leaf chlorophyll. - HortScience 25: 330-331, 1990.

Cannell M.G.R.: Crop physiological aspects of coffee bean yield: A review. - J. Coffee Res. 5: 7-20, 1975.

Cao K.F., Ohkubo T.: Allometry, root/shoot ratio and root architecture in understory saplings of deciduous dicotyledonous trees in central Japan. - Ecol. Res. 13: 217-227, 1998.

Cheng W.Y., Akanda J.M.H., Nyam K.L.: Kenaf seed oil, a potential new source of edible oil. - Trends Food Sci. Tech. 52: 57-65, 2016.

Freese D., Böhm C., Quinkenstein A. et al.: The contribution of agroforestry systems to ecosystem serives. $17^{\text {th }}$ World Congress of the International Commission of Agriculture and Biosystems Engineering, Canada 2010.

Gilmore A.M.: Mechanistic aspects of xanthophyll cycledependent photoprotection in higher plant chloroplasts and leaves. - Physiol. Plantarum 99:197-209, 1997.

Han C.J., Wang Q., Zhang H.B. et al.: Light shading improves the yield and quality of seed in oil-seed peony (Paeonia ostii Feng Dan). - J. Integr. Agr. 17:1631-1640, 2018.

Han J.G., Li X.Q., Liu Z. et al.: [Potential applications of tree peony as an oil plant.] - Cereal Oil 5: 21-25, 2014. [In Chinese]

Hong D.Y., Pan K.Y., Zhou Z.Q.: [Circumscription of Paeonia suffruticosa Andrews and identification of cultivated tree peonies.] - Acta Phytotaxon. Sin. 42: 275-283, 2004. [In Chinese]

Huang W.J., Sun X.C., Wang N. et al.: [Panax japonicus var. major: Shading affecting growth and development and photosynthetic physiological characteristics.] - Chin. Agric. Sci. 34: 49-53, 2018. [In Chinese]

Jose S.: Agroforestry for ecosystem services and environmental benefits: An overview. - Agroforest. Syst. 76: 1-10, 2009.

Kim K.B., Nam Y.A., Kim H.S. et al.: $\alpha$-Linolenic acid: Nutraceutical, pharmacological and toxicological evaluation. Food Chem. Toxicol. 70: 163-178, 2014.

Lichtenthaler H.K., Ač A., Marek M.V. et al.: Differences in pigments composition, photosynthetic rates and chlorophyll fluorescence images of sun and shade leaves of four tree species. - Plant Physiol. Bioch. 45: 577- 588, 2007.

Mielke M.S., Schaffer B., Li C.: Use of a SPAD meter to 
estimate chlorophyll content in Eugenia uniflora L. leaves as affected by contrasting light environments and soil flooding. Photosynthetica 48: 332-338, 2010.

Müller P., Li X.P., Niyogi K.K.: Non-photochemical quenching. A response to excess light energy. - Plant Physiol. 125: 15581566, 2001.

Nasielski J., Furze J.R., Tan J. et al.: Agroforestry promotes soybean yield stability and $\mathrm{N}_{2}$-fixation under water stress. Agron. Sustain. Dev. 35: 1541-1549, 2015.

Pang K.J., Sambeek J.W.V., Navarrete-Tindall N.E. et al.: Responses of legumes and grasses to non-, moderate, and dense shade in Missouri, USA. I. Forage yield and its specieslevel plasticity. - Agroforest. Syst. 93: 25-38, 2019.

Peng L.P., Cai C.F., Zhong Y. et al.: Genetic analyses reveal independent domestication origins of the emerging oil crop Paeonia ostii, a tree peony with a long-term cultivation history. - Sci Rep.-UK 7: 5340, 2017.

Perfecto I., Rice R.A., Greenberg R. et al.: Shade coffee: A disappearing refuge for biodiversity. - BioScience 46: 598-608, 1996.

Pfitsch W.A., Pearcy R.W.: Daily carbon gain by Adenocaulon bicolor (Asteraceae), a redwood forest understory herb, in relation to its light environment. - Oecologia 80: 465-470, 1989.

Powles S.B.: Photoinhibition of photosynthesis induced by visible light. - Ann. Rev. Plant Physio. 35: 15-44, 1984.

Sanou J., Bayala J., Teklehaimanot Z., Bazié P.: Effect of shading by baobab (Adansonia digitata) and néré (Parkia biglobosa) on yields of millet (Pennisetum glaucum) and taro (Colocasia esculenta) in parkland systems in Burkina Faso, West Africa. - Agroforest. Syst. 85: 431-441, 2012.

Surhone L.M., Timpledon M.T., Marseken S.F. et al.: Paeonia ostii. Pp. 4-5. Betascript Publishing, Hong Kong 2010.

Tang Z.H., Shen Z.G., Ding X. et al.: [Effects of shading on photosynthetic characteristics in Paeonia ostii cv. 'Phoenix White' seedlings.] - Nonwood Forest Res. 35: 84-89, 2017. [In Chinese]

Valladares F., Pearcy R.W.: Interactions between water stress, sun-shade acclimation, heat tolerance and photoinhibition in the sclerophyll Heteromeles arbutifolia. - Plant Cell
Environ. 20: 25-36, 2010.

Wang C.Z., Ma H.Z., Song Z.P. et al.: [Seasonal dynamics of biomass allocation of Paeonia ostii 'Fengdan' and the effects of tree age and shading.] - Plant Sci. J. 35: 884-893, 2017. [In Chinese]

Wu T.G., Yu M.K., Wu M., Xiao J.H.: Seasonal variation in photosynthesis in relation to differing environmental factors of dominant plant species in three successional communities in Hangzhou Bay Wetlands, East China. - Russ. J. Ecol+ 42: 471-479, 2011.

Xiang M.A., Zhu C.C.: [Compound cultivation techniques of pecan and white tea in hilly area of Southern Jiangsu Province.] - Mod. Agr. Sci. Tech. 17: 62-63, 2016. [In Chinese]

Xu S.Q., Liu Q., Huang S.W. et al.: [Studies on general situation of oilseed peony intercropping with woods in China.] Xiandai Horticult. 14: 28-30, 2017. [In Chinese]

Xue J.P., Wang X., Zhang A.M. et al.: [Effects of shading on photosynthetic characteristics of Pinellia ternata leaves.] China J. Chin. Mater. Med. 33: 2896-2900, 2008. [In Chinese]

Yang J., Ji W.L., Liu L. et al.: [Effects of plant-row spacing on growth and yield components of oil tree peony Paeonia ostii 'Feng Dan'.] - J. Arid Land Res. Environ. 31: 202-208, 2017. [In Chinese]

Zhang C.Y., Fang Y.M., Ji H.L., Ma C.T.: [Effects of shading on photosynthesis characteristics of Photinia $\times$ frasery and Aucuba japonica var. variegata.] - Appl. Ecol. J. 22: 17431749, 2011. [In Chinese]

Zhang Y., Chang H., Deng C.W. et al.: [Studies on the effects of shading on photosynthetic characteristics of Zantedeschia.] J. Shanxi Agric. Sci. 43: 14-16, 2015. [In Chinese]

Zhang Z.H., Tang Z.H., Yang F.J. et al.: [Photosynthetic characteristics and its micro-environmental limiting factors of two main oil peony.] - Bull. Bot. Res. 34: 770-775, 2014. [In Chinese]

Zhou S.G., Kong X.S., Zhang M.X. et al.: [Effects of shading on photosynthesis and other physiological and biochemical characteristics in tree peony.] - Sci. Silv. Sin. 46: 56-60, 2010. [In Chinese]

(C) The authors. This is an open access article distributed under the terms of the Creative Commons BY-NC-ND Licence. 